\title{
Simultaneous multiplex Polymerase Chain Reaction detection of Salmonella spp., Escherichia coli O157, Vibrio parahaemolyticus, Vibrio cholerae, Listeria monocytogenes and Campylobacter spp.
}

\author{
${ }^{1}$ Ling, S., ${ }^{1}$ Noramirah, R., ${ }^{1}$ Abidatul, A.A., ${ }^{1}$ Nurfarhanah, N.M.J., ${ }^{1,2}$ Noor-Azira, A.M., \\ ${ }^{1,2}$ Jambari, N.N., ${ }^{3}$ Ungku Fatimah, U.Z.A., ${ }^{1}$ New, C.Y. and ${ }^{1,2, *}$ Son, R. \\ ${ }^{1}$ Department of Food Science, Faculty of Food Science and Technology, Universiti Putra Malaysia, 43400 \\ UPM Serdang, Selangor Darul Ehsan, Malaysia \\ ${ }^{2}$ Food Safety and Food Integrity, Institute of Tropical Agriculture, Universiti Putra Malaysia, 43400 UPM \\ Serdang, Selangor Darul Ehsan, Malaysia \\ ${ }^{3}$ Department of Food Service and Management, Faculty of Food Science and Technology, Universiti Putra \\ Malaysia, 43400 UPM Serdang, Selangor Darul Ehsan, Malaysia
}

\author{
Article history: \\ Received: 30 November 2017 \\ Received in revised form: 2 \\ January 2018 \\ Accepted: 6 January 2018 \\ Available Online: 17 January \\ 2018
}

Keywords:

Multiplex PCR

Foodborne pathogens

Diagnostic tool

Optimisation

Food safety

DOI:

https://doi.org/10.26656/fr.2017.2(3).002

\begin{abstract}
Foodborne illness is a global burden that impacts a country politically, economically and socio-economically. The severity of the burden can be unmeasurable as foodborne illness is often an underestimated problem. In order to enlighten the burden, appropriate food safety control measures should be taken. This study aimed to optimize a multiplex Polymerase Chain Reaction (mPCR) detection method to identify foodborne pathogens simultaneously. Six foodborne pathogens namely, Salmonella spp., Escherichia coli O157, Vibrio parahaemolyticus, Vibrio cholerae, Listeria monocytogenes and Campylobacter spp., were targeted in the mPCR detection method. Each mPCR parameter was tested and the outcome was analysed to obtain a successful mPCR protocol to detect the targeted foodborne pathogens. The amplified PCR products showed that the optimized mPCR protocol will be a potential rapid diagnostic tool in foodborne pathogen detection.
\end{abstract}

\section{Introduction}

Foodborne disease is caused by consumption of food that is contaminated by pathogens. Most of the diseasecausing germs are infectious. In addition, harmful toxins and chemicals can also cause foodborne illness. The symptoms of foodborne disease can range from mild, self-limiting to severe with permanent damage. Children, the elderly, pregnant women, and the immunocompromised persons are greatly at risk when they contract foodborne pathogens. The impact of foodborne disease is greatly displayed in developing countries with wide economic inequality, particularly the African regions and South-East Asia regions. Furthermore, the tropical climate of these regions favours the growth of foodborne pathogens. The burden of foodborne disease impacts the economy of a country, particularly challenging the tourist, agricultural and food (export) industries (World Health Organization, (WHO) 2015).

Foodborne disease in Malaysia was reported to be fluctuating year by year (New, Ubong, Premarathne et al., 2017). The total incident rate of food and waterborne diseases in Malaysia in 2015 was 50.32 per 100,000 population while the mortality rate of was 0.05 per 100,000 population according to Ministry of Health (MOH) Malaysia (2016). Among the diseases listed, food poisoning had the highest incident rate $(47.34 \%)$, followed by typhoid $(1.42 \%)$, cholera $(0.80 \%)$ and dysentery $(0.41 \%)$. However, this might not be the exact number of cases reported due to the rigid and strenuous protocols of reporting an outbreak. Additionally, not many who contracted foodborne disease will seek medical treatment due to the self-limiting symptoms.

Salmonella spp. (Najwa et al., 2015), Escherichia coli O157 (Radu et al., 1998), Vibrio parahaemolyticus, Vibrio cholerae (Letchumanan, 2013), Listeria monocytogenes (Goh, 2013) and Campylobacter spp. (New, Wong, Usha et al., 2017) are among the common foodborne pathogens in Malaysia. In the recent food poisoning cases (2013 - 2016), Salmonella was identified as the causative agent (Food Safety News, 2014; Astro Awani, 2014; Koris, 2016). Salmonellosis, a disease caused by non-typhoidal Salmonella is commonly associated with poultry, eggs, as well as meat, unpasteurized milk and juices, cheese, raw fruits and 
vegetables, and spices and nuts (Nguyen et al., 2016). Centers for Disease Control and Prevention (CDC) reported about half of the outbreaks of STEC in the United States from 2011 to 2014 were caused by E. coli O157: H7 also known as STEC O157, and contaminated ground beef and raw vegetables as the common food vehicles for infection. The low infectious dose of $E$. coli O157: H7 (10 - $100 \mathrm{CFU})$ is the reason for high number of cases in outbreaks (Settanni and Corsetti, 2007; Lim et al., 2010; Nguyen et al., 2016). In addition, E. coli infection is more common in lower-income countries (WHO, 2017). L. monocytogenes is associated with milk, dairy products, eggs, poultry and meat, and causes listeriosis. Listeriosis has a high mortality rate in immunocompromised populations, such as HIV/AIDS and chronic disease patients, elderly, pregnant women and unborn children. L. monocytogenes is a concern in the food industry as it often contaminates ready-to-eat food (Nguyen et al., 2016). According to WHO Regional Office for South-East Asia (SEARO) (2012), the incidence of listeriosis varied between 0.1 and 11.3 cases per 1, 000, 000 population per year in different countries. $V$. cholerae and $V$. parahaemolyticus are found in brackish and marine water, and prevalent in seafood, such as shrimp, shellfish, and finfish (Wei et al., 2014). These two Vibrio species have caused several outbreaks of diarrhoea especially $V$. cholerae for the seven cholera pandemics, and sporadic infections worldwide (Vinothkumar et al., 2013). Campylobacter infection or Campylobacteriosis is caused by consumption of drinking water, unpasteurised milk, and poultry which are contaminated by Campylobacter spp. (Silva et al., 2011). It is a significant public health hazard due to low infective dose, the serious sequelae, virulence genes and the clinical infection pattern (Al Amri et al., 2007).

The traditional method for detecting foodborne pathogens is a combination of selective cultivation techniques with standard biochemical tests. It is timeconsuming, laborious and produces sampling and enumerating errors as well as subjective interpretation. This method also does not allow rapid detection of more than one pathogens in a large quantity of food samples. As a result, over the past few decades, researchers have developed various types of rapid methods based on molecular knowledge to detect pathogens in food samples. By mixing several sets of specific primers into a single PCR assay. Multiplex PCR (mPCR) is one of the well-known molecular methods that are able to detect multiple pathogens simultaneously in a single reaction. The advantages of using mPCR are that the method is sensitive, saves time and effort as well as laboratory cost (Settanni and Corsetti, 2007; Chen et al., 2012). There have been many studies done in the last decade in successfully developing $\mathrm{mPCR}$ procedures for simultaneous detection of three different foodborne pathogens (Park et al., 2006; Germini et al., 2009; AlJobori et al., 2016; Nguyen et al., 2016; Trimoulinard et al., 2017). mPCR is a very useful tool which has been used by other researchers to detect five different foodborne pathogens (Chen et al., 2012), distinguish between five closely-related Salmonella spp. (Tan, 2015) and also detect five virulence genes in E. coli $\mathrm{O} 157: \mathrm{H} 7$ (Jeshveen et al., 2012).

The development of rapid methods becomes a resource tool in the control of food safety and at the same time strengthening the capacity of countries to conduct assessment (WHO, 2017). Often the method development should be economical and in line with the national food safety systems. As such, there is a strive to develop more rapid methods. This study focused on the optimisation of simultaneous detection of six foodborne pathogens, which were Salmonella spp., E. coli O157, V. parahaemolyticus, $V$. cholerae, L. monocytogenes and Campylobacter spp. using mPCR.

\section{Materials and methods}

\subsection{Preparation of bacterial strains}

The six bacterial strains (Salmonella spp., $L$. monocytogenes, E. coli O157, V. parahaemolyticus and $V$. cholerae and Campylobacter spp.) were acquired from Bacteriology Food Safety Lab, UPM in glycerol stocks. The bacterial strains were revived by subculturing them in $10 \mathrm{ml}$ Tryptic Soy Broth (TSB) and incubated at $37^{\circ} \mathrm{C}$ for $18-24$ hours. At the same time, each strain was sub-cultured onto nutrient agar plates. For $V$. parahaemolyticus and $V$. cholerae, the strains are sub-cultured in $10 \mathrm{ml}$ TSB with $1 \%$ sodium chloride, $\mathrm{NaCl}$ and on nutrient agar plates with $1 \% \mathrm{NaCl}$. The revived bacterial strains were then sub-cultured onto their respective selective agars for confirmation. Salmonella spp. on Xylose Lysine Deoxycholate (XLD) agar; L. monocytogenes on PALCAM agar; E. coli O157 on Eosin Methylene Blue (EMB) agar; $V$. parahaemolyticus and $V$. cholerae on Thiosulphate Bile Citrate Sucrose (TCBS) agar; Campylobacter spp. on Campylobacter Blood-Free Selective Medium. All media and chemicals used were purchased from Merck, Germany.

\subsection{Preparation of DNA template}

Confirmed bacterial strains were then subjected to DNA template extraction. Prior to that, the bacterial strains were sub-cultured into TSB and incubated at $37^{\circ}$ C for $18-24$ hours to obtain bacterial suspensions. Genomic DNA was extracted from the bacterial strain using modified boiling cell method following the method 
described by Tang et al. (2009) with modification. One $\mathrm{ml}$ of bacterial suspension was transferred into $1.5 \mathrm{ml}$ microcentrifuge tube. The tube was centrifuged at 10000 rpm for 3 mins. The supernatant was discarded, and the pellet was resuspended in $500 \mu \mathrm{l}$ of sterile distilled water and then vortexed. The suspension was boiled for 10 mins, followed by immediate cooling at $-20^{\circ} \mathrm{C}$ for 10 mins, then centrifuged at $10000 \mathrm{rpm}$ for $1 \mathrm{~min}$.

\subsection{PCR amplification}

Optimisation of PCR was carried out by performing singleplex first, then multiplex. Singleplex was performed by mixing $1 \mathrm{X}$ PCR buffer, $2.0 \mathrm{mM}$ of $\mathrm{MgCl}_{2}$, $0.2 \mathrm{mM}$ of deoxyribonucleotide phosphate mix, $0.2 \mu \mathrm{M}$ of primers, $1 \mathrm{U}$ Taq DNA Polymerase and $2 \mu \mathrm{l}$ of DNA template. The mixture was topped up with sterile distilled water to have the final volume of $25 \mu 1$. For the amplification, the samples underwent pre-denaturation at $95^{\circ} \mathrm{C}$ for 5 minutes and then cycled for 35 times of $95^{\circ} \mathrm{C}$ for $30 \mathrm{~s}, 55^{\circ} \mathrm{C}$ for $30 \mathrm{~s}, 72^{\circ} \mathrm{C}$ for $30 \mathrm{~s}$ before incubated at $72^{\circ} \mathrm{C}$ for $7 \mathrm{~min}$ for the final extension and hold at $4^{\circ} \mathrm{C}$. Primers used in this study were listed in Table 1.

There were several parameters adjusted in the optimisation of mPCR. The parameters include: 1 . annealing temperature $\left(55-60^{\circ} \mathrm{C}\right) ;$ 2. $\mathrm{MgCl}_{2}$ concentration, (2.5-4.5 mM); 3. Primers concentration [Vc hlyA primer concentration $(0.3-0.6 \mu \mathrm{M})$, C23SrRNA primer concentration $(0.15-0.30 \mu \mathrm{M})$, StyinvaJHO-2 primer concentration $(0.2-0.4 \mu \mathrm{M}), \mathrm{Vp}$ toxR primer concentration $(0.1-0.2 \mu \mathrm{M}), \quad r f b E$ primer concentration $(0.2-0.3 \mu \mathrm{M})]$; 4 . deoxyribonucleotide phosphate (dNTP) mix concentration $(0.3-0.5 \mathrm{mM}) ; 5$. Taq DNA polymerase concentration (1.5-2.0 U) and; 6 . PCR buffer concentration $(1-1.5 \mathrm{X})$.

The final optimised protocol of the MPCR was performed in a $25 \mu \mathrm{l}$ mixture containing $1.4 \mathrm{X}$ PCR
Buffer, $3.0 \mathrm{mM} \mathrm{MgCl2}, 0.3 \mathrm{mM}$ dnTP mix, $0.1 \mu \mathrm{M}$ of $\mathrm{Vp}$ tox $R$ primer, $0.5 \mu \mathrm{M}$ of $\mathrm{Vc} h l y A$ primer, $0.2 \mu \mathrm{M}$ of-of $r f b E$, LM- $h l y A$ and Styinva-JHO-2 primer pairs and, 0.15 $\mu \mathrm{M}$ of C-23SrRNA primers, $1.5 \mathrm{U}$ of Taq DNA Polymerase and $2.0 \mu \mathrm{L}$ of DNA template. The PCR amplification was performed following pre-denaturation $95^{\circ} \mathrm{C}$ for 5 mins, 35 cycles of denaturation at $95^{\circ} \mathrm{C}$ for 30 $\mathrm{s}$, annealing at $55^{\circ} \mathrm{C}$ for $45 \mathrm{~s}$ and extension at $72^{\circ} \mathrm{C}$ for $30 \mathrm{~s}$, then final extension at $72^{\circ} \mathrm{C}$ for 7 mins and lastly hold at $4^{\circ} \mathrm{C}$.

All primers used in this study were purchased from Sigma Aldrich, Malaysia while the PCR reagents were purchased from Promega, USA.

\subsection{Gel electrophoresis}

Both singleplex and multiplex PCR products were separated on a $1.25 \%(\mathrm{w} / \mathrm{v})$ agarose gel in $0.5 \mathrm{X}$ TrisBorate-EDTA (TBE) buffer. The gel was pre-stained with Florosafe DNA Stain (1 ${ }^{\text {st }}$ base, Malaysia) and electrophoresed at $90 \mathrm{~V}$ for 30 minutes and $60 \mathrm{~V}$ for 1 hour for singlplex and multiplex system respectively. The gel was then viewed under UV light using Gel Documentation System (Syngene, USA). The lengths of amplified products were estimated by comparison against a 100 bp DNA Ladder (Promega, USA).

\section{Results and discussion}

Figure 1 shows the PCR products that were successfully amplified. In Figure 1, inv $A$ amplicon (119 bp) for Salmonella spp., hlyA amplicon (210 bp) for $L$. monocytogenes, rfbE amplicon (296 bp) for E. coli O157, toxR amplicon (368 bp) for $V$. parahaemolyticus, hlyA amplicon (427 bp) for $V$. cholerae, and 23S rRNA amplicon (650 bp) for Campylobacter spp. were identified easily via different amplicon sizes. When

Table 1. List of primers used in MPCR

\begin{tabular}{|c|c|c|c|c|c|}
\hline Target Pathogens & Primers & Primer sequence $5^{\prime}$ to $3^{\prime}$ & $\begin{array}{c}\text { Product } \\
\text { length (bp) }\end{array}$ & $\begin{array}{l}\text { Target } \\
\text { Gene }\end{array}$ & References \\
\hline \multirow{2}{*}{ Salmonella spp. } & Styinva-JHO- 2 - F & TCGTCATTCCATTACCTACC & \multirow{2}{*}{119} & \multirow{2}{*}{ invA } & \multirow{2}{*}{$\begin{array}{l}\text { Hoorfar et al } \\
\quad(2000)\end{array}$} \\
\hline & Styinva-JHO- 2 - R & AAACGTTGAAAAACTGAGGA & & & \\
\hline \multirow{2}{*}{$\begin{array}{l}\text { Escherichia coli } \\
\text { O157 }\end{array}$} & $r f b E-\mathrm{F}$ & CAGGTGAAGGTGGAATGGTTGTC & \multirow{2}{*}{296} & \multirow{2}{*}{$r f b E$} & \multirow{2}{*}{$\begin{array}{l}\text { Bertrand and } \\
\text { Roig (2007) }\end{array}$} \\
\hline & $r f b E-\mathrm{R}$ & TTAGAATTGAGACCATCCAATAAG & & & \\
\hline \multirow{2}{*}{$\begin{array}{l}\text { Vibrio } \\
\text { parahaemolyticus }\end{array}$} & $\mathrm{Vp}$ tox $R-\mathrm{F}$ & ATACGAGTGGTTGCTGTCATG & \multirow{2}{*}{368} & \multirow{2}{*}{$\operatorname{tox} R$} & \multirow{2}{*}{$\begin{array}{l}\text { Kim et al. } \\
\text { (1999) }\end{array}$} \\
\hline & $\mathrm{Vp}$ tox $R-\mathrm{R}$ & GTCTTCTGACGCAATCGTTG & & & \\
\hline \multirow{2}{*}{ Vibrio cholerae } & Vc hlyA-F & CAATCGTTGCGCAATCGCG & \multirow{2}{*}{427} & \multirow{2}{*}{ hlyA } & \multirow{2}{*}{$\begin{array}{l}\text { Vinothkuma } \\
\text { et al. (2013) }\end{array}$} \\
\hline & Vc hlyA-R & TAATAAGCGAGCGGTACG & & & \\
\hline \multirow{2}{*}{$\begin{array}{l}\text { Listeria } \\
\text { monocytogenes }\end{array}$} & $\mathrm{LM}-h l y A-\mathrm{F}$ & CGCAACAAACTGAAGCAAAGG & \multirow{2}{*}{210} & \multirow{2}{*}{ hlyA } & \multirow{2}{*}{$\begin{array}{l}\text { Park et al. } \\
\quad(2006)\end{array}$} \\
\hline & $\mathrm{LM}-h l y A-\mathrm{R}$ & TTGGCGGCACATTTGTCAC & & & \\
\hline \multirow{2}{*}{$\begin{array}{l}\text { Campylobacter } \\
\text { spp. }\end{array}$} & C-23SrRNA-F & TATACCGGTAAGGAGTGCTGGAG & \multirow{2}{*}{650} & \multirow{2}{*}{$\begin{array}{c}23 \mathrm{~S} \\
\text { rRNA }\end{array}$} & \multirow{2}{*}{$\begin{array}{l}\text { Wang et al. } \\
\quad(2002)\end{array}$} \\
\hline & C-23SrRNA-R & АTCAATTAACCTTCGAGCACCG & & & \\
\hline
\end{tabular}


developing a mPCR detection method, the amplicon sizes of the PCR product must be taken note based on the selected primers. Preferably, the difference between each amplicon should be not less than $100 \mathrm{bp}$ and not more than $900 \mathrm{bp}$ difference. This allows quicker separation during electrophoresis and maintaining the rapidness of the method. The primer design or selection if the primers are adopted must be ensured that they are not complementary to each other to ensure successful multiplexing and avoid cross-reactivity between primers and amplification of unwanted DNA fragments (Sint et al., 2012). During the optimisation, it was noted that the parameters that affected the $\mathrm{mPCR}$ the most were the annealing temperature and the primer's concentration.

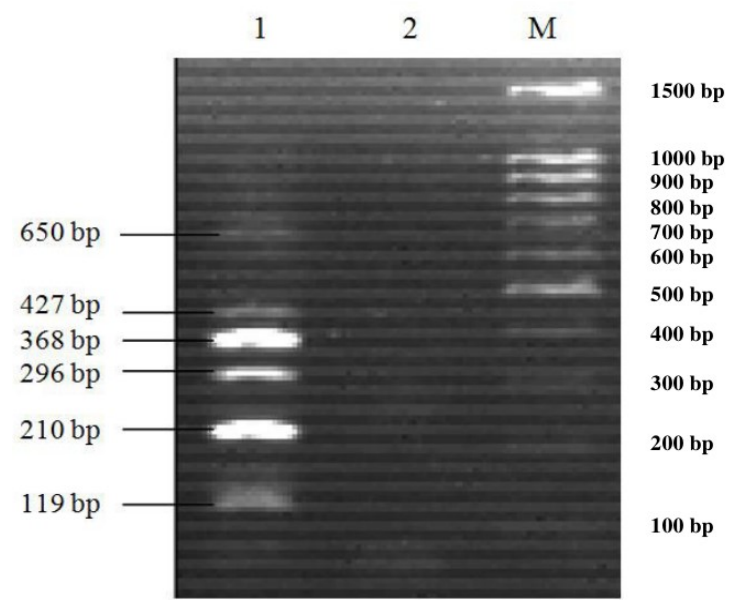

Figure 1. PCR amplification product of $\mathrm{mPCR}$ for simultaneous detection of six foodborne pathogens. M - 100 bp DNA ladder (Promega, USA). Lane 1- invA amplicon (119 bp) for Salmonella spp., hlyA amplicon (210 bp) for $L$. monocytogenes, $r f b E$ amplicon (296 bp) for E. coli O157, toxR amplicon (368 bp) for $V$. parahaemolyticus, hlyA amplicon (427 bp) for $V$. cholerae, and 23S rRNA amplicon (650 bp) for Campylobacter spp. Lane 2- negative control.

In mPCR, it is essential to have all primers pairs work within the same range of melting temperature. Hence, prior to the mPCR optimisation, singleplex was performed to estimate the optimal range of the annealing temperature for each primer to produce the desired product (Sint et al., 2012). The optimal range of the annealing temperature was then tested during multiplexing containing single extracts and a mixture of the bacterial templates to ensure that the right PCR products are produced. In this study, it was observed the invA amplicon for Salmonella spp. disappeared when the annealing temperature was increased to $56^{\circ} \mathrm{C}$. Subsequent raise of the annealing temperature observed low signal strength (unclear bands) for the amplification of invA for Salmonella spp. Hence, it was deduced that the optimal annealing temperature for the multiplex was at $55^{\circ} \mathrm{C}$ whereby all targets produced the best signal strength.

Multiplexing single extracts will allow the developer to test the primers' specificity in which the exact primer pair should work in amplifying the target gene. In addition, it is also to check if there is any potential formation of primer cross-dimers (Sint et al., 2012). This occurred when there is a primer interaction, usually weak interactions that produce non-specific products (Brownie et al., 1997). Primer cross-dimers can be observed below $100 \mathrm{bp}$ which often indicates a high concentration of primers being used or complementary primer pairs with no target amplification produced. It was observed that no primer cross-dimers were formed during the amplification (Figure 1), signifying the complete use of primers at the right concentration.

However, the amplicons showed unequal signal strength (Figure 1). hlyA amplicon for $V$. cholerae, 23S rRNA amplicon for Campylobacter spp. and invA amplicon for Salmonella spp. showed the same equal signal strength while toxR amplicon for $V$. parahaemolyticus, rfbE amplicon for E. coli $\mathrm{O} 157$ and hlyA amplicon for L. monocytogenes showed strong signal strength. This was one problem and the second problem noted in this study was the existence of nonspecific product at the range of $120-150 \mathrm{bp}$. Throughout the optimisation, the primer concentrations were adjusted stepwise. This was done by starting off at the equal concentration of the primers $(0.2 \mu \mathrm{M})$, observing the results and subsequently reducing the concentration of primers that produced stronger bands and increasing the primers that produced weaker bands. By balancing the primers' concentration, this yield a higher primer efficiency according to their varying amplification efficiency (Sint et al., 2012). The final result as shown in Figure 1 was the best yield as the DNA template was not quantified.

C-23S rRNA primer pair was noted to be the cause of the non-specific product within the multiplex system which can be due to several other factors such as PCR inhibitors in the reaction. Hence, the reduction of the $\mathrm{C}$ $23 \mathrm{~S}$ rRNA primer had successfully eliminated the nonspecific product but produced weaker signal strength. Primer concentration that is slightly under will cause the PCR product unable to accumulate exponentially to exhibit strong signal (Markoulatos et al., 2002). On the other hand, $\mathrm{Vc}-$ hly A primers did not produce any targeted bands at low primer concentration in this study due to reason aforementioned. The increase of the primer concentration up to $0.5 \mu \mathrm{M}$ produced a yield and further increase only produced higher primer dimer intensity.

To further suppress the production of non-specific bindings, hot-start PCR was employed (D'Aquila et al., 1991; Chou et al., 1992) coupled with higher PCR buffer concentration. The PCR buffer concentration consists of 
$\mathrm{KCl}$ salt and Tri-HCl. The potassium salt reduces repulsive force between negatively-charged phosphate backbones of DNA double strands by neutralizing the charges. It facilitates annealing of primer to DNA template and stabilizes the primer-template structure (Rajendran, 2014). As the non-specific product was captured between $120-150 \mathrm{bp}$, the specificity was improved by increasing the potassium salt concentration according to Lorenz (2012).

The $\mathrm{MgCl}_{2}$ concentration was also manipulated to further enhance the signal strength and reduce the nonspecific bindings. It should be noted too that multiplexing more than 4 targets required a higher concentration of $\mathrm{MgCl}_{2}$. Insufficient $\mathrm{MgCl}_{2}$ concentration will lower the yield of a product or results in no amplicon production (Markoulatos et al., 2002; Lorenz, 2012) while excessive $\mathrm{MgCl}_{2}$ beyond $3.0 \mathrm{mM}$ in the presence of the enzyme will cause spurious priming to non-specific template site, lowering the specificity and producing undesired products (Markoulatos et al., 2002; Jeshveen et al., 2012). Furthermore, the free $\mathrm{Mg}^{2+}$ ion will react with unbound dNTPs to form soluble complexes to produce the PCR amplicons. A balanced ratio of dNTPs and unbound $\mathrm{Mg}^{2+}$ will form amplicons with high specificity. Increasing concentration of dNTPs can immediately stop the PCR amplification as the increased amount of dNTPs will reduce the amount of $\mathrm{Mg}^{2+}$ ions that are available for the reaction (Markoulatos et al., 2002; Roux, 2009; Jeshveen et al., 2012). The final concentration of $\mathrm{MgCl}_{2}$ and $\mathrm{dNTP}$ for the multiplex system to work best was at $3.0 \mathrm{mM}$ and 0.3 $\mathrm{mM}$ respectively.

To ensure the best optimisation of a mPCR, primer/ assay sensitivity should be measured to validate the method. Theoretically, PCR is known as a specific and sensitive method as minute amounts of DNA templates is sufficient to achieve stable detection. This should be maintained within the multiplex system as multiple targets can be detected at low copies of DNA templates and avoiding biased detection rates (Sint et al., 2012). The sensitivity can be gradually affected when there are large amounts of other taxa as well as PCR inhibitors. This study is in agreement with Sint et al. (2012) to use standard bacterial pathogens and quantify the DNA template before the start of optimising. It will improve the precision of the method by reducing the biasness, improves the sensitivity and also reduce workload.

In food safety, this specific, sensitive and rapid detection method will be able to finely discriminate the pathogens (Institute Food Technologist (IFT), 2000) and to provide leverage in early detection. Further, this helps in ensuring the safe food supply through identifying the routes of contamination and preventing foodborne diseases (Law et al., 2014). Additionally, this approach allows one to study on the epidemiological of the foodborne pathogens and its evolution via downstream molecular analysis. Most importantly, it helps in building the capacity of assessment commitment in food industries. It is hoped that this successfully optimised method could be used in the pathogen surveillance system in Malaysia and in other countries burdened with foodborne illness.

\section{Conflicts of Interest}

The authors declare no conflicts of interest.

\section{Acknowledgements}

Research fund was sponsored by the Universiti Putra Malaysia Grant GP-IPS 2015 (GP-IPS/2015/9466100).

\section{References}

Al Amri, A., Senok, A.C., Ismaeel, A.Y., Al-Mahmeed, A.E. and Botta, G.A. (2007). Multiplex PCR for direct identification of Campylobacter spp. in human and chicken stools. Journal of Medical Microbiology, 56, 1350-1355. https:// doi.org/10.1099/jmm.0.47220-0

Al-Jobori, K.M., Hasan, M.L.M. and Nader, M.I. (2016). Detection of E. coli, Salmonella spp., and Listeria monocytogenes in retail chicken meat and chicken giblets samples using multiplex PCR in Baghdad city. International Journal of Current Microbiology and Applied Sciences, 5(9), 290-301. https:// doi.org/0.20546/ijcmas.2016.509.033

Astro Awani. (2014). 5-year-old boy's death linked to Salmonella bacteria. Retrieved on May 17, 2017 from http://english.astroawani.com/malaysia-news/5year-oldboys-death-linked-salmonella-bacteria31233

Bertrand, R. and Roig, B. (2007). Evaluation of enrichment-free PCR-based detection on the $r f b E$ gene of Escherichia coli O157- application to municipal wastewater. Water Resources, 41, 12801286. https://doi.org/10.1016/j.watres.2006.11.027

Brownies, J., Shawcross, S., Theaker, J., Whitcombe, D., Ferried, R., Newton, C. and Little, S. (1997). The elimination of primer-dimer accumulation in PCR. Nucleic Acids Research, 25, 3235-3241. https:// doi.org/10.1093/nar/25.16.3235

Chen, J., Tang, J., Liu, J., Cai, Z. and Bai, X. (2012). Development and evaluation of a multiplex PCR for simultaneous detection of five foodborne pathogens. Journal of Applied Microbiology, 112(4), 823-830. 
https://doi.org/10.1111/j.1365-2672.2012.05240.x

Chou, Q., Russell, M., Birch, D.E., Raymond, J. and Bloch, W. (1992). Prevention of pre-PCR mispriming and primer dimerization improves low-copy -number amplifications. Nucleic Acids Research, 20, 1717-1723. https://doi.org/10.1093/nar/20.7.1717

D’Aquila, R.T., Bechtel, L.J., Videler, J.A., Eron, J.J., Gorczyca, P. and Kaplan, J.C. (1991). Maximizing sensitivity and specificity of PCR by preamplification heating. Nucleic Acids Research, 19, 3749. https://doi.org/10.1093/nar/19.13.3749

Food Safety News. (2014). 158 students in Malaysia sickened by foodborne Illness. Retrieved on January 4, 2018 from: http:// www.foodsafetynews.com/2014/02/158-students-inmalaysia-sick-with-food-poisoning/\#.V2yng_197Dc.

Germini, A., Masola, A., Carnevali, P. and Marchelli, R. (2009). Simultaneous detection of Escherichia coli O175: H7, Salmonella spp., and Listeria monocytogenes by multiplex PCR. Food Control, 20, 733-738.

j.foodcont.2008.09.010

Goh, S.G. (2013). Prevalence, risk and antibiogram of Listeria monocytogenes in raw chicken meat. Selangor, Malaysia: Universiti Putra Malaysia, MSc Thesis.

Hoorfar, J., Ahrens, P. and Rådström, P. (2000). Automated 5' nuclease PCR assay for identification of Salmonella enterica. Journal of Clinical Microbiology, 38, 3429-3435.

Institute of Food Technologist (IFT). (2000). IFT Expert Report on Emerging Microbiological Food Safety Issues. Retrieved on January 5, 2018 from IFT website: http://www.ift.org/ /media/Knowledge\% 20Center/Science\%20Reports/Expert\%20Reports/ Emerging\%20Microbiological/Emerging\% 20Micro.pdf

Jeshveen, S.S., Chai, L.C., Pui, C.F. and Son, R. (2012). Optimisation of multiplex PCR conditions for rapid detection of Escherichia coli O157:H7 virulence genes. International Food Research Journal, 19(2), 461-466.

Kim, Y.B., Okuda, J., Matsumoto, C., Takahashi, N., Hashimoto, S. and Nishibuchi, M. (1999). Identification of Vibrio parahaemolyticus strains at the species level by PCR targeted to the toxR gene. Journal of Clinical Microbiology, 37, 1173-1177.

Koris, N.N.S (2016). Tapah school food poisoning caused by Salmonella contamination. Retrieved on April 25, 2017 from: http://www.nst.com.my/ news/2016/04/137696/tapah-school-food-poisoningcaused-salmonella-contamination
Law, J.W-F., Ab Mutalib, N-S., Chan, K-G. and Lee, LH. (2014). Rapid methods for the detection of foodborne bacterial pathogens: principles, applications, advantages and limitations. Frontiers in Microbiology, 5, 770. https://doi.org/ 10.3389/ fmicb.2014.00770

Letchumanan, V. (2013). Detection of Vibrio cholerae and Vibrio parahaemolyticus in seafood using MPNPCR techniques, and their molecular characteristics. Selangor, Malaysia: Universiti Putra Malaysia, MSc Thesis.

Lim, J.Y., Yoon, J.W. and Hovde, C.J. (2010). A Brief Overview of Escherichia coli O157:H7 and Its Plasmid O157. Journal of Microbiology and Biotechnology, 20(1), 5-14.

Lorenz, T.C. (2012). Polymerase chain reaction: Basic protocol plus troubleshooting and optimisation strategies. Journal of Visualized Experiments, 63, e3998. https://doi.org/10.3791/3998

Markoulatos, P., Siafakas, N. and Moncany, M. (2002). Multiplex polymerase chain reaction: A practical approach. Journal of Clinical Laboratory Analysis, 16(1), 47-51. https://doi.org/10.1002/jcla.2058

Ministry of Health (MOH), Malaysia. (2016). Health facts. Retrieved from $\mathrm{MOH}$ website: http:// www.moh.gov.my/images/gallery/publications/ KKM\%20HEALTH\%20FACTS\%202016.pdf

Najwa, M.S., Rukayadi, Y., Ubong, A., Loo, Y.Y., Chang, W.S., Lye, Y.L., Thung, T.Y., Aimi, S.A., Malcolm, T.T.H, Goh, S.G., Kuan, C.H., Yoshitsugu, N., Nishibuchi, M. and Son, R. (2015). Quantification and antibiotic susceptibility of Salmonella spp., Salmonella Enteritidis and Salmonella Typhimurium in raw vegetables (ulam). International Food Research Journal, 22(5), 17611769.

New, C.Y., Ubong, A., Premarathne, J.M.K.J.K., Thung, T.Y., Lee, E., Chang, W.S., Loo, Y.Y., Kwan, S.Y., Tan, C.W., Kuan, C.H. and Son, R. (2017). Microbiological food safety in Malaysia from the academician's perspective. Food Research, 1(6), 183 -202. https://doi.org/10.26656/fr.2017.6.013

New, C.Y., Wong, C.Y., Usha, M., Ubong, A., Nakaguchi, Y., Nishibuchi, M. and Son, R. (2017). Level of Campylobacter jejuni from naturally contaminated chicken liver and chicken legs in various task: a cross contamination study. Food Research, 1(2), 33-37. https://doi.org/10.26656/ fr.2017.2.010

Nguyen, T.T., Van Giau, V. and Vo, T.K. (2016). Multiplex PCR for simultaneous identification of $E$. coli O157:H7, Salmonella spp. and $L$. 
monocytogenes in food. 3 Biotech, 6(2), 1-9. https:// doi.org/10.1007/s13205-016-0523-6

Park, Y.S., Lee, S.R. and Kim, Y.G. (2006). Detection of Escherichia coli O157: H7, Salmonella spp., Staphylococcus aureus and Listeria monocytogenes in Kimchi by multiplex polymerase chain reaction (mPCR). Journal of Microbiology, 44(1), 92-97.

Radu, S., Mutalib, S.A. and Rusul, G. (1998). Detection of Escherichia coli O157: H7 in the beef marketed in Malaysia. Applied and Environmental Microbiology, 64(3), 1153-1156

Rajendran, S.R.C.K. (2014). Roles of $\mathrm{KCl}$ and $\mathrm{MgCl}_{2}$ in PCR. Biotech Articles. Retrieved from: http:// www.biotecharticles.com/Biotech-Research-Article/ Role-of-KCl-and-MgCl2-in-PCR-3271.html

Roux, K.H. (2009). Optimisation and troubleshooting in PCR. Cold Spring Harbor Protocols, 4(4), 1-7. https://doi.org/10.1101/pdb.ip66

Settanni, L. and Corsetti, A. (2007). The use of multiplex PCR to detect and differentiate food- and beverageassociated microorganisms: A review. Journal of Microbiological Methods, 69, 1-22. https:// doi.org/10.1016/j.mimet.2006.12.008

Silva, J., Leite, D., Fernandes, M., Mena, C., Gibbs, P.A. and Teixeira, P. (2011). Campylobacter spp. as a foodborne pathogen: a review. Frontiers in Microbiology, 2(200), 1-12. https://doi.org/10.3389/ fmicb.2011.00200

Sint, D., Raso, L. and Traugott, M. (2012). Advances in multiplex PCR: balancing primer efficiencies and improving detection success. Methods in Ecology and Evolution, 3, 898-905. https://doi.org/ 10.1111/ j.2041-210X.2012.00215.X

Tan, C.L.L. (2015). Development and Optimisation Of a Multiplex PCR Assay For Simultaneous Detection of Salmonella Enteritidis, Salmonella Typhimurium, Salmonella Weltevreden, Salmonella Agona, and Salmonella Heidelberg. Pulau Pinang, Malaysia: Universiti Sains Malaysia, MSc Thesis.

Tang, J.Y.H., Mohamad Ghazali, F., Saleha, A.A., Nishibuchi, M. and Son, R. (2009). Comparison of thermophilic Campylobacter spp. occurrence in two types of retain chicken samples. International Food Research Journal, 16, 277-288.

Trimoulinard, A., Beral, M., Henry, I., Atiana, L., Porphyre, V., Tessier, C., Leclercq, A. and Cardinale, E. (2017). Contamination by Salmonella spp., Campylobacter spp. and Listeria spp. of most popular chicken- and pork-sausages sold in Reunion Island. International Journal of Food Microbiology, 250, 68-74. https://doi.org/10.1016/ j.ijfoodmicro.2017.03.017
Vinothkumar, K., Bhardwaj, A.K., Ramamurthy, T. and Niyogi, S.K. (2013). Triplex PCR assay for the rapid identification of 3 major Vibrio species, Vibrio cholerae, Vibrio parahaemolyticus, and Vibrio fluvialis. Diagnostic Microbiology and Infectious Disease, 76, 526-528. https://doi.org/10.1016/ j.diagmicrobio.2013.04.005

Wang, G., Clark, C.G., Taylor, T.M., Pucknell, C., Barton, C., Price, L., Woodward, D.L. and Rodgers, F.G. (2002). Colony Multiplex PCR Assay for Identification and Differentiation of Campylobacter jejuni, C. coli, C. lari, C. upsaliensis, and C. fetus subsp. fetus. Journal of Clinical Microbiology, 40 (12), 4744-4747. https://doi.org/10.1128/ JCM.40.12.4744-4747.2002

Wei, S., Zhao, H., Xian, Y., Hussain, M.A. and Wu, X. (2014). Multiplex PCR assays for the detection of Vibrio alginolyticus, Vibrio parahaemolyticus, Vibrio vulnificus, and Vibrio cholerae with an internal amplification control. Diagnostic Microbiology and Infectious Disease, 79(2), 115$118 . \quad$ https://doi.org/10.1016/ j.diagmicrobio.2014.03.012

WHO Regional Office for South-East Asia (SEARO). (2012). Retrieved on January 4, 2018 from WHO SEARO website: http://www.searo.who.int/entity/ emerging_diseases/Zoonoses_Listeriosis.pdf?ua $=1$

World Health Organization (WHO). 2017. Retrieved on April 29, 2017 from WHO website: Emergencies preparedness, response. Enterohaemorrhagic Escherichia coli. http://www.who.int/csr/don/ archive/disease/ehec/en/

World Health Organization, (WHO). (2015). WHO Estimates of the Global Burden of Foodborne Diseases. Geneva: WHO. 